\title{
INFORMAÇÕES
}

\section{O EMPRÊGO DO PETROLEO NA CURA DA MALÁRIA}

Com referencia à noticia aqui divulgada, procedente dos Estados Unidos, sôbre o emprêgo do petroleo na cura da malária, transcreveremos. abaixo a entrevista do professor Manoel José Ferreira a um dos nossos vespertinos:

"Sinto-me um tanto embaraçado", disse o Dr. Ferreira, " em emitir opinião sôbre a noticia enviada pelo correspondente da Associated Press de Virginia, nos Estados Unidos, a respeito de "O petroleo da California no combate à malária"

A "noticia", provavelmente em virtude de varias manipulações, veio a público, aquí no Rio, tão estropiada, que se torna praticamente impossivel saber onde buscar, já não digo a originalidade ou novidade do assunto, mas, pelo menos, o seu lado util e prático.

"- Abrindo um parentesis" - acrescentou o Dr. Ferreira, - "devo dizer que os malariogistas de todo o mundo recebem com justa reserva qualquer produto, combinação ou método de tratamento, que se apresente com credenciais avantajadas sôbre os alcalóides da quina, os derivados da quinolina ou os da acridina. Sôbre eles, o tempo e a fartura de observações em hospitais e campanhas constituem um repositório de tal magnitude, que qualquer novidade precisará passar através duras provas, antes de poder entrar em plano equivalente. O estado atual de nossos conhecimentos em malariologia torna imperativa semelhante reserva. A grande complexidade dos fatores que intervêm no problema da malária, quer sob o ponto de vista clínico, quer epidemiológico, que terapêutico, faz com que o maior flagelo rural da humanidade se apresente no tempo, no espaço e em cada individuo, com aspectos desconcertantemente variaveis.

Estas circunstâncias explicam muitas das esperanças justificadas a principio no uso de medicamentos e sistemas terapêuticos; que com o: correr do tempo vieram a perder o fastigio a que se haviam elevado, por um conjunto fortuito de condições propicias.

Semelhantemente às doenças contagiosas ou transmissiveis para as quais existem "medicamentos especificos", a malária se encontra otimamente bem armada, sendo, via de régra, os fracassos observados mais em virtude de tratamento tardio ou mal conduzido, do que pela precariedade dos remédios existentes.

"- Encerrado o parentesis -" prosseguiu o Dr. Manoel Ferreira "devo confessar a minha surpresa lógo aq constatar que o jornalista emprestaria ao Sr. Alfred Burger a asserção de que o petroleo da California "póde suplantar a famosa cinchona (sic), a rica árvore medicinal, como fonte de recursos para o combate aos milhões de enfermos da malária no Estados Unidos".

Derivados do petroleo no tratamento do impaludismo não constituem nenhuma novidade. Desde 1933, que os alemães, francêses e russos industrializaram êsses produtos derivados da acridina sob varios nomes comerciais, constituindo-se em grande vantagem para o arsenal terapêtico da malária, "sem contudo suplantar os alcalóides da quina", cuja excelencia 
ninguem contesta, mesmo entre os preconizadores de qualquer outro medicamento de origem diversa.

As informações sôbre a "toxidez" dos referidos derivados, especialmente para o lado do sistema nervoso é que o Sr. Burger "espera remover", constituem um velho "tendão de Achilles" dos derivados do petroleo, mostrando claramente que "ainda" teremos que continuar esperando que seja removido êsse inconveniente, que não é, aliás, peculiar apenas ao derivado do petroleo californiano".

Concluindo suas declarações, disse o Dr. Ferreira:

“- O que, porém, merece um reparo especial na noticia é o. receio de que a possibilidade de extenșão da guerra às Indias Orientais Holandêsas venha privar as Américas de quinina, "sendo assim necessário preparar-se um sucêdaneo". Sejam quais forem os caprichos da guerra, jamais ficaremos privados dêsse especifico da malaria, e muito menos por isso seremos levados a procurar um sucêdaneo.

Aproveito para dizer que seria de alto alcance, para coíbir oscilações de terço ou mesmo uma possivel delonga nas importações, que o Governo fizesse um estoque dos sáis mais empregados de quinina, afim de atender aos seus proprios serviços e socorrer, em caso de emergência, os numerosos industriais que fabricam produtos à base dêsses alcalóides. Nêsse sentido, dei um parecer recente, quando exercia as furções de assistente técnico de malariologia da Divisão de Saúde Publica do Departamento Nacional de Saúde, estudando, então, as nossas necessidades e o estado de nossos estóques.

Creado que foi ultimamente o Serviço Nacional de Malária, seria oportuno retornar à questão.

\title{
Novidades bibliograficas.
}

\section{ENDOCRINOLOGIA}

\author{
Compendio teorico-pratico
}

\author{
pelo Prof. DR. D. M. GONZALEZ TORRES
}

Um volume encadernado em tela, com 350 pgs. e 53 figuras.

\section{Preço do exemplar: $60 \$ 000$}

Pedidos: Luiz Dubrez. Rua S. Bento, 357, 2. ${ }^{\circ}$ and. S. 3 